\title{
PENGEMBANGAN KURIKULUM SEKOLAH DASAR
}

\author{
Ruma Mubarak ${ }^{1}$
}

\begin{abstract}
Education is an effort to prepare students to be able live well in the society, able to develop and improve the quality of their own lives, and contribute significantly in developing and improving the quality of society and nation. There are six main problems in the national education system, (1) decline moral and character of students, (2) equitable distribution of learning opportunities, (3) low internal efficiency of the education system, (4) institutional status, (5) management of education that is not in line with the national development, (6) resources are not professional. In this case, need for social change which gives the direction that education is a basic approach in the change process. Education is life, therefore learning activities should be able to equip students with life skills (life competency) that appropriate with the environment and their lives.
\end{abstract}

Keywords: Curriculum Development, Elementary School

\section{A. Pendahuluan}

Pendidikan adalah upaya untuk mempersiapkan peserta didik agar mampu hidup dengan baik dalam masyarakatnya, mampu mengembangkan dan meningkatkan kualitas hidupnya sendiri, serta berkontribusi secara bermakna dalam mengembangkan dan meningkatkan kualitas masyarakat dan bangsanya (Nanang, 2000: 1).

Sementara itu, ada indikasi yang menunjukkan bahwa mutu pendidikan di Indonesia masih belum meningkat secara signifikan. Dari dalam negeri diketahui bahwa NEM SD (Nilai Ebtanas Murni Sekolah Dasar) sampai sekolah menengah relatif rendah dan tidak mengalami peningkatan yang berarti. Dari dunia usaha juga muncul keluhan bahwa lulusan yang memasuki dunia kerja belum memiliki kesiapan kerja yang baik. Ketidakpuasan berjenjang juga terjadi, lulusan SD kurang baik untuk mengikuti pembelajaran di Sekolah Menengah, dan kalangan perguruan tinggi merasa bekal lulusan sekolah menengah belum cukup untuk mengikuti perkuliahan (Depdiknas, 2001: 1).

1 Dosen Fakultas Ilmu Tarbiyah Dan Keguruan Universitas Islam Negeri Maulana Malik Ibrahim Malang Jl. Gajayana No. 50 Malang 65144 
Tilaar mengemukakan bahwa pendidikan nasional dewasa ini sedang dihadapkan pada empat krisis pokok yang berkaitan kuantitas dan kualitas, relevansi atau efisiensi eksternal, elitisme dan manajemen. Lebih lanjut dikatakan bahwa setidaknya ada enam masalah pokok dalam sistem pendidikan nasional. (1) menurunnya akhlak dan moral peserta didik, (2) pemerataan kesempatan belajar, (3) masih rendahnya efisiensi internal sistem pendidikan, (4) status kelembagaan, (5) manajemen pendidikan yang tidak sejalan dengan pembangunan nasional, (6) sumber daya yang belum profesional. (Tilaar, 1994: 16).

Menghadapi hal tersebut, perlu dilakukan pemerataan terhadap sistem pendidikan secara kaffah (menyeluruh), terutama berkaitan dengan kualitas pendidikan, serta relevansinya dengan kebutuhan masyarakat dan dunia kerja.

Secara idel (teoritis) perubahan kurikulum dimungkinkan terjadi setelah dilaksanakan selama sepuluh tahun, itupun harus didasari oleh hasil pengkajian dan penilaian secara mendalam. Di samping itu, kurikulum harus dinamis dan adaptif terhadap segala perubahan yang terjadi di tengah-tengah masyarakat yang terus berkembang. Dinamis berarti terus berkembang menuju arah yang lebih baik dan menjawab tantangan zaman, adaptif berarti mampu menjawab kebutuhan-kebutuhan yang dirasakan serta diperlukan oleh masyarakat. Tampaknya pihak Depdiknas menilai bahwa kurikulum 1994 sudah ketinggalan zaman (out of date) yang sudah tidak mampu lagi menjawab tantangan dunia yang semakin kompetitif, tidak mampu lagi menjawab kebutuhan masyarakat (Kwartolo, 2002: 79).

Selain itu kurikulum 1994 masih menggunakan pendekatan penguasaan materi, sarat materi (over loaded) dan isinya tumpang tindih (over lapping). Kurikulum ini masih cenderung berorientasi hanya pada kognisi. Dalam hal ini masih mengorientasikan pengajarannya pada pendidikan akademis yakni mendidik anak-anak menjadi cerdas dan pandai menghafal rumus-rumus.

\section{B. Konsep Pengembangan Kurikulum}

Menurut Nasution dalam kajian Ahmad (1998: 10) istilah kurikulum berasal dari atletik yaitu curere yang berarti berlari. Dari istilah atletik, kurikulum mengalami pergeseran arti kedunia pendidikan, yakni sejumlah mata pelajaran diperguruan tinggi. 
Menurut Muhaimin (2003: 182) pengertian kurikulum dalam arti yang sempit merupakan seperangkat rencana dan pengaturan tentang isi dan bahan pelajaran serta cara yang digunakan sebagai pedoman penyelenggaraan kegiatan belajar mengajar di sekolah. Pengertian ini mengeris bawahi adanya 4 (empat) komponen pokok dalam kurikulum, yaitu tujuan, isi/ bahan, organisasi dan strategi.

Sedangkan pengertian kurikulum secara luas, kurikulum merupakan segala kegiatan yang dirancang oleh lembaga pendidikan untuk disajikan kepada peserta didik guna mencapai tujuan pendidikan (institusional, kurikuler, dan intruksional).

Pengertian kurikulum sebagaimana tercantum dalam UUSPN No.20 Tahun 2003 adalah sebagai seperangkat rencana dan pengaturan mengenai tujuan, isi, dan bahan pelajaran serta cara yang digunakan sebagai pedoman penyelenggaraan kegiatan pembelajaran untuk mencapai tujuan pendidikan tertentu. (UUSPN, No. 20 Tahun 2003, Bab 1 Ayat 19)

Sedangkan pengembangan kurikulum (curriculum development) menurut Audrey Nicholls dan S. Howard Nichools adalah: the planning of learning opportunities intended to bring about certain desered in pupils, and assessment of the extent to wich these changes have taken plece (Hamalik, 2006: 96).

Berdasarkan rumusan diatas dapat diketahui bahwa pengembangan kurikulum adalah perencanaan kesempatan-kesempatan belajar yang dimaksudkan untuk membawa siswa ke arah perubahan-perubahan yang diinginkan dan menilai hingga mana perubahan-perubahan itu telah terjadi pada diri siswa. Dalam pengertian itu, sesungguhnya pengembangan kurikulum adalah proses siklus, yang tidak pernah berakhir.

\section{Prinsip Pengembangan Kurikulum}

Prinsip umum pengembangan kurikulum menyangkut 5 hal yaitu (Sukmadinata, 2005: 151).

1. Prinsip Relevansi

Ada dua macam relevansi yang harus dimiliki kurikulum, yaitu relevansi keluar dan relevansi di dalam kurikulum itu sendiri. Relevansi keluar maksudnya tujuan, isi, dan proses belajar yang tercakup 
dalam kurikulum hendaknya relevan dengan tuntutan, kebutuhan, dan perkembangan masyarakat. Kurikulum juga harus memiliki relevansi di dalam yaitu ada kesesuaian atau konsistensi antara komponen-kompoenen kurikulum, yaitu antara tujuan, isi, proses penyampaian, dan penilaian. Relevansi internal ini merupakan suatu keterpaduan kurikulum.

2. Prinsip Fleksibilitas

Prinsip fleksibilitas menunjukkan bahwa kurikulum adalah tidak kaku. Hal ini berarti bahwa di dalam penyelenggaraan proses dan program pendidikan harus diperhatikan kondisi perbedaan yang ada di dalam diri peserta didik. Ahmad (1998: 71)

3. Prinsip Kontinuitas

Prinsip kesinambungan dalam pengembangan kurikulum menunjukkan adanya saling terkait antara tingkat pendidikan, jenis program pendidikan, dan bidang studi. (Ahmad, 1998: 71)

4. Prinsip Praktis

Kurikulum harus mudah dilaksanakan, menggunakan alat-alat sederhana dan biayanya juga murah. Prinsip ini juga disebut prinsip efesiensi. (Sukmadinata, 2005: 151). Efisiensi merupakan perbandingan antara hasil yang dicapai dan pengeluaran (berupa waktu, tenaga, dan biaya) yang diharapkan paling tidak menunjukkn hasil yang seimbang. (Ahmad, 1998: 70)

5. Prinsip Efektivitas

Dalam dunia pendidikan, masalah efektivitas dapat ditinjau dari segi efektifitas mengajar guru dan efektifitas belajar murid. Efektivitas mengajar guru menyangkut sejauh mana jenis-jenis kegiatan mengajar yang direncanakan dapat dilaksanakan dengan baik. Efektivitas belajar murid menyangkut sejauh mana tujuantujuan pelajaran yang diinginkan dapat dicapai melalui kegiatan belajar mengajar yang ditempuh. (Ahmad, 1998: 117)

\section{Kurikulum Berbasis Kompetensi}

Kurikulum Berbasis Kompatansi (KBK) dapat diartikan sebagai suatu konsep kurikulum yang menekankan pada pengembangkan 
kemampuan melakukan (kompetensi) tugas-tugas dengan standar performans tertentu, sehingga hasilnya dapat dirasakan oleh peserta didik, berupa penguasaan terhadap seperangkat kompetensi tertentu. (Mulyasa, 2002: 39).

Dalam dokumen kurikulum 2004 dirumuskan bahwa kurikulum berbasis kompetensi merupakan perangkat rencana dan pengaturan tentang kompetensi dan hasil balajar yang harus dicapai oleh siswa, penilaian kegiatan belajar mengajar, dan penberdayaan sumberdaya pendidikan. (Depdiknas, 2002)

Kurikulum berbasis kompetensi berorientasi pada : (1) hasil dan dampak yang diharapkan muncul pada diri peserta didik melalui serangkaian penglaman belajar yang bermakna dan (2) keberagaman yang dapat di infestasikan sesuai dengan kebutuhannya.

Terdapat tiga landasan teoritis yang mendasari KBK. Pertama, adanya pergesaran dari pembelajaran kelompok, kearah pembelajaran individual. Kedua, pengembangan konsep belajar tuntas (Mastery Learning) atau belajar sebagai penguasaan (Learning for Mastery) adalah suatu falsafah pembelajaran yang mengatakan bahwa dalam sistem pembelajaran yang tepat semua peserta didik dapat mempelajari semua bahan yang diberikan dengan hasil yang baik. Ketiga, pendefinisian kembali kepada bakat.

\section{Landasan Kurikulum Berbasis Kompetensi}

Pengembangan kurikulum berbasis kompetensi berlandaskan pada fungsi dan tujuan pendidikan nasional sebagaimana yang tercantum dalam undang-undang No. 20 tahun 2003 tentang sistem pendidikan nasional.

"Pendidikan nasional befungsi mengembangkan kemampuan dan membentuk watak serta peradaban bangsa yang bermartabat dalam rangka mencerdaskan kehidupan banngsa, betujuan untuk berkembangnya potensi peserta didik agar menjadi manusia yang beriman dan bertaqwa kepada Tuhan Yang Maha Esa, berakhlak mulia, sehat, berilmu, cakap, kreatif, mandiri, dan menjadi warga negara yang demokratis serta tangguang jawab".

Landasan hukum pusat penetapan kebijakan umum dan pengembangan kompetensi menurut PP No. 25 tahun 2000 pasal 2 ayat 2 yaitu kewenangan daerah adalah membuat silabus, panduan-panduan 
pembelajaran dan penilaian sesuai dengan kebutuhan masing-masing dan menentukan sumber-sumber belajar yang cocok untuk mendukung pembelajaran. (Depdiknas, 2002)

\section{Tujuan Kurikulum Berbasis Kompetensi}

Tujuan kurikulum berbasis kompetensi adalah mendirikan atau memberdayakan sekolah dalam mengembangkan kompetensi yang akan disampaikan pada peserta didik, sesuai dengan kondisi lingkungan.

Manfaat diterapkannya kurikulum berbasis kompetensi adalah sebagai berikut:

a. Bagi siswa: memperoleh pendidikan yang lebih sesuai dengan kebutuhan perkembangan dan perkembangan psikologisnya.

b. Bagi guru: Memperoleh kelonggaran untuk memanfaatkan keahlian profesionalnya baik dalam pengelolaan pembelajaran maupun peningkatan potensi dan kesenangan belajar siswa.

c. Bagi masyarakat: Memiliki peluang untuk merekrut tamatan sesuai dengan kebutuhan baik di pendidikan lanjutan dunia nyata maupun dunia kerja. (Workshop MGMP, 2002: 6)

\section{Karakteristik Kurikulum Berbasis Kompetensi}

Depdiknas mengemukakan bahwa kurikulum berbasis kompetensi memiliki karakteristik sebagai berikut:

a. Menekankan pada ketercapaian kompetensi siswa baik secara individual maupun klasikal.

b. Berorientasi pada hasil belajar (learning outcomes) dan keberagaman.

c. Penyampaian dalam pembelajaran menggunakan pendekatan atau metode yang bervariasi.

d. Sumber belajar bukan hanya guru, tetapi juga sumber belajar lainnya yang memenuhi unsur edukatif.

e. Penilaian menekankan pada proses dan hasil belajar dalam upaya penguasaan dan pencapaian suatu kompetensi. (Mulyasa, 2003: 42)

Lebih lanjut, dari berbagai sumber sedikitnya dapat diidentifikasi 
enam karakteristik kurikulum berbasis kompetensi, yaitu: (a) sistem modul; (b) menggunakan keseluruhan sumber belajar; (c) pengalaman lapangan; (d ) statagi individual personal; (e) kemudahan belajar; dan (f) belajar tuntas.

\section{Tabel 1 : Perbedaaan Kurikulum Berbasis Materi Dengan Kurikulum Berbasis Kompetensi (KBK)}

\begin{tabular}{|c|c|c|}
\hline Aspek & Kurikulum Berbasis Materi & Kurikulum Berbasis Kompetensi \\
\hline Peran guru & \begin{tabular}{|ll} 
- & $\begin{array}{l}\text { Sumber informasi utama } \\
\text { Pentransfer pengetahuan/ } \\
\text { ilmu }\end{array}$ \\
\end{tabular} & 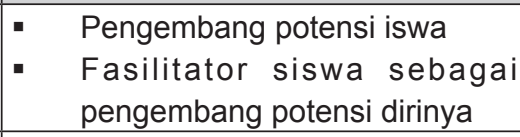 \\
\hline $\begin{array}{l}\text { Sumber } \\
\text { belajar }\end{array}$ & $\begin{array}{ll} & \text { Guru } \\
\text { - } & \text { Buku pelajaran }\end{array}$ & $\begin{array}{ll}\text { - } & \text { Lingkungan fisik, sosial dan } \\
\text { budaya } \\
\text { - } & \text { Beragam sumber belajar }\end{array}$ \\
\hline $\begin{array}{l}\text { Alat bantu } \\
\text { pelajaran }\end{array}$ & $\begin{array}{ll}\text { - } & \text { Konvensional } \\
\text { Dropping dari pusat/ } \\
\text { pemerintah }\end{array}$ & $\begin{array}{ll}\text { - } & \text { ABP sederhana dan murah } \\
\text { buatan guru dan siswa } \\
\text { - } \\
\text { ABP dari pusat/pemerintah hanya } \\
\text { pelengkap }\end{array}$ \\
\hline $\begin{array}{l}\text { Persiapan } \\
\text { Mengajar }\end{array}$ & $\begin{array}{l}\text { Mode I s a t u a n } \\
\text { pembelajaran }\end{array}$ & $\begin{array}{l}\text { - } \begin{array}{l}\text { Beragam bentuk tergantung } \\
\text { keinginan dan kemampuan } \\
\text { guru }\end{array} \\
\end{array}$ \\
\hline Penilaian & $\begin{array}{l}\text { Fokus hasil belajar } \\
\text { penguasaan materi } \\
\text { domain : kognitif } \\
\text { Acuan :PAN } \\
\text { Prinsip : diskriminasi } \\
\text { siswa } \\
\text { Bentuk penilaian tertulis } \\
\text { Teknik penilai isian } \\
\text { singkat, benar salah, } \\
\text { pilihan ganda } \\
\text { Ciri domain : penilain } \\
\text { sumatif } \\
\text { penekanan: pengukuran/ } \\
\text { penilaian kuantitatif }\end{array}$ & $\begin{array}{ll}\text { - } & \text { Taraf pencapaian kompetensi } \\
\text { - } & \text { Kognitif, afe ktif dan } \\
\text { - } & \text { Patokan acuan kriteria } \\
\text { - } & \text { Tertulis. Unjuk kerja, lisan dan } \\
\text { - } & \text { Bingkah laku } \\
\text { - } & \text { Peragam teknilaian formatif (terutama } \\
& \text { penilaian proses) dan penilain } \\
\text { - } & \text { Pumatif (tes dan non tes) } \\
& \text { Penilaian kualitatif }\end{array}$ \\
\hline
\end{tabular}

\section{Prinsip Pengembangan dan Pelaksanaan Kurikulum Berbasis Kompetensi}

Sesuai dengan asas-asas yang mendasarinya, proses pengembangan KBK harus dilakukan dengan memperhatikan beberapa prinsip. Setiap prinsip pengembangan dan pelaksanaan KBK seperti yang dirumuskan 
depdiknas dalam kerangka dasar kurikulum 2004 seperti berikut:

a. Prinsip Pengembangan

Terdapat sejumlah prinsip yang harus diperhatikan dalam proses pengembangan KBK, yaitu:

1. Peningkatan keimanan, budi pekerti luhur, dan penghayatan nilai-nilai budaya.

2. Keseimbangan etika, logika, estetika, dan kinestetika.

3. Penguatan Integritas Nasional.

4. Perkembangan Pengatahuan dan Teknologi Informasi.

5. Pengembangan Kecakapan Hidup.

6. Pilar Pendidikan.

7. Komprehensif dan Berkesinambungan.

8. Balajar Sepanjang Hayat.

9. Diversifikasi kurikulum.

b. Prinsip Pelaksanaan

1) Prinsip ini mengandung pengertian, bahwa melalui KBK penyediaan tempat yang memberdayakan semua peserta didik secara demokratis dan berkeadilan untuk memperoleh pengetahuan, ketrampilan dan sikap sangat diutamakan.

2) Barpusat pada Anak

3) Pendekatan Menyeluruh dan Kemitraan

4) Kesatuan dalam Kebijakan dan Keberagaman dalam Pelaksanaan. (Depdiknas, 2002)

\section{E. Konsep Dasar Kurikulum Tingkat Satuan Pendidikan}

\section{a. Pengertian Kurikulum Tingkat Satuan Pendidikan}

Dalam Standar Nasional Pendidikan (SNP Pasal 1, ayat 15) dikemukakan bahwa Kurikulum Tingkat Satuan Pendidikan (KTSP) adalah kurikulum operasional yang disusun dan dilaksanakan oleh masing-masing satuan pendidikan. (Mulyasa, 2006: 20)

KTSP disusun dan dikembangkan berdasarkan Undang-Undang 
N0. 20 Tahun 2003 tentang Sistem Pendidikan Nasional pasal 36 ayat 1 dan 2 sebagai berikut:

1. Pengembangan kurikulum mengacu pada Standar Nasional Pendidikan untuk mewujudkan Tujuan Pendidikan Nasional.

2. Kurikulum pada semua jenjang dan jenis pendidikan dikembangkan dengan prinsip diversifikasi sesuai dengan satuan pendidikan, potensi daerah, dan peserta didik.

KTSP merupakan strategi pengembangan kurikulum untuk mewujudkan sekolah yang efektif, produktif, dan berprestasi. KTSP merupakan paradigma baru pengembangan kurikulum, yang memberikan otonomi luas pada setiap satuan pendidikan, dan pelibatan masyarakat dalam rangka mengefektifkan proses belajar-mengajar di sekolah. (Mulyasa, 2006: 21)

\section{b. Tujuan Kurikulum Tingkat Satuan Pendidikan}

Secara umum tujuan diterapkannya KTSP adalah untuk memandirikan dan memberdayakan satuan pendidikan melalui pemberian kewenangan (otonomi) kepada lembaga pendidikan dan mendorong sekolah untuk melakukan pengambilan keputusan secara partisipatif dalam pengembangan kurikulum.

Secara khusus tujuan diterapkannya KTSP adalah untuk:

a. Meningkatkan mutu pendidikan melalui kemandirian dan inisiatif sekolah dalam mengembangkan kurikulum, mengelola dan memberdayakan sumber daya yang tersedia.

b. Meningkatkan kepedulian warga sekolah dan masyarakat dalam pengembangan kurikulum melalui pengambilan keputusan bersama.

c. Meningkatkan kompetisi yang sehat antar satuan pendidikan tentang kualitas pendidikan yang akan dicapai. (Mulyasa, 2006: 22)

\section{c. Komponen Kurikulum Tingkat Satuan Pendidikan}


Dalam garis besarnya KTSP memiliki enam komponen penting sebagai berikut.
a. Visi dan misi
b. Tujuan pendidikan satuan pendidikan
c. Menyusun kalender pendidikan
d. Struktur muatan KTSP
e. Silabus
f. RPP. (Mulyasa, 2006: 176)

\section{d. Perbedaan Kurikulum 1994 dengan Kurikulum 2006}

Perbedaan kurikulum 1994 dengan kurikulum 2006 minimal ada tiga perbedaan yang mendasar yaitu: (Joko Susilo, : 102)

Tabel 2: Perbedaan Kurikulum 1994 Dengan Kurikulum 2006

\begin{tabular}{|l|l|l|l|}
\hline No & \multicolumn{1}{|c|}{ Aspek } & \multicolumn{1}{|c|}{ Kurikulum '94 } & \multicolumn{1}{c|}{ Kurikulum '06 } \\
\hline 1. & $\begin{array}{l}\text { Kewenangan } \\
\text { pengembangan }\end{array}$ & $\begin{array}{l}\text { Seluruhnya berada } \\
\text { di tangan pusat dan } \\
\text { daerah hanya kebagian } \\
\text { pengembangan } \\
\text { kurikulum lokal dengan } \\
\text { porsi 80\% pusat dan } \\
\text { 20\% daerah }\end{array}$ & $\begin{array}{l}\text { Pusat hanya } \\
\text { mengembangkan } \\
\text { kompetensi sebagai } \\
\text { standar sedangkan } \\
\text { elaborasi kompetensi } \\
\text { diserahkan daerah/ } \\
\text { sekolah dalam bentuk } \\
\text { silabus }\end{array}$ \\
\hline 2. & $\begin{array}{l}\text { Pendekatan } \\
\text { pembelajaran }\end{array}$ & $\begin{array}{l}\text { Sebagian besar } \\
\text { berbasis konten/isi }\end{array}$ & $\begin{array}{l}\text { Berbasis kompetensi } \\
\text { 3. }\end{array}$ \\
\hline $\begin{array}{l}\text { Penataan isi/ } \\
\text { konten (struktur } \\
\text { program) }\end{array}$ & $\begin{array}{l}\text { materi, jam belajar, dan } \\
\text { struktur program }\end{array}$ & $\begin{array}{l}\text { Terjadi penataan materi, } \\
\text { jam belajar, dan struktur } \\
\text { program }\end{array}$ \\
\hline
\end{tabular}

Sedangkan Mulyasa (2003: 166) mengidentifikasi perbedaan kurikulum '94 dengan kurikulum berbasis kompetensi menjadi sembilan macam, antara lain:

Tabel 3: Perbedaan Kurikulum 1994 Dengan Kurikulum 2004 


\begin{tabular}{|c|c|c|}
\hline No & Kurikulum ‘94 & $\begin{array}{c}\text { Kurikulum Berbasis } \\
\text { Kompetensi }\end{array}$ \\
\hline 1. & $\begin{array}{l}\text { Menggunakan pendekatan } \\
\text { penguasaan ilmu pengetahuan, } \\
\text { yang menekankan pada isi atau } \\
\text { materi berupa pengetahuan, } \\
\text { pemahaman, aplikasi, analisis, } \\
\text { sintesis, dan evaluasi yang } \\
\text { diambil dari bidang-bidang ilmu } \\
\text { pengetahuan }\end{array}$ & $\begin{array}{l}\text { Menggunakan pendekatan } \\
\text { kompetensi yang menekankan } \\
\text { pada pemahaman, kemampuan atau } \\
\text { kompetensi tertentu di sekolah yang } \\
\text { berkaitan dengan pekerjaan yang } \\
\text { ada di masyarakat }\end{array}$ \\
\hline 2. & $\begin{array}{l}\text { Standar akademis yang diterapkan } \\
\text { secara seragam bagi setiap peserta } \\
\text { didik }\end{array}$ & $\begin{array}{l}\text { Standar kompetensi yang } \\
\text { memperhatikan perbedaan individu, } \\
\text { baik kemampuan, kecepatan belajar, } \\
\text { maupun konteks sosial budaya }\end{array}$ \\
\hline 3. & $\begin{array}{l}\text { Berbasis konten, sehingga peserta } \\
\text { didik dipandang sebagai kertas } \\
\text { putih yang perlu ditulisi dengan } \\
\text { sejumlah ilmu pengetahuan (transfer } \\
\text { knowledge) }\end{array}$ & $\begin{array}{l}\text { Berbasis kompetensi, sehingga } \\
\text { peserta didik berada dalam proses } \\
\text { perkembangan yang berkelanjutan } \\
\text { dari seluruh aspek kepribadian, } \\
\text { sebagai pemekaran terhadap } \\
\text { potensi-potensi bawaan sesuai } \\
\text { dengan kesempatan belajar yang } \\
\text { ada dan diberikan oleh lingkungan }\end{array}$ \\
\hline 4. & $\begin{array}{l}\text { Pengembangan kurikulum } \\
\text { dilakukan secara sentralisasi, } \\
\text { sehingga Depdiknas memonopoli } \\
\text { pengembangan ide dan konsepsi } \\
\text { kurikulum }\end{array}$ & $\begin{array}{l}\text { Pengembangan kurikulum dilakukan } \\
\text { secara desentralisasi, sehingga } \\
\text { pemerintah dan masyarakat } \\
\text { bersama-sama menentukan standar } \\
\text { pendidikan yang dituangkan dalam } \\
\text { kurikulum }\end{array}$ \\
\hline 5. & $\begin{array}{l}\text { Materi yang dikembangkan dan } \\
\text { diajarkan di sekolah sering kali tidak } \\
\text { sesuai dengan potensi sekolah, } \\
\text { kebutuhan dan kemampuan peserta } \\
\text { didik, serta kebutuhan masyarakat } \\
\text { sekitar sekolah }\end{array}$ & $\begin{array}{l}\text { Sekolah diberi keleluasaan untuk } \\
\text { menyusun dan mengembangkan } \\
\text { silabus mata pelajaran sehingga } \\
\text { dapat mengakomodasi potensi } \\
\text { sekolah, kebutuhan dan kemampuan } \\
\text { peserta didik, serta kebutuhan } \\
\text { masyarakat sekitar sekolah }\end{array}$ \\
\hline 6. & $\begin{array}{l}\text { Guru merupakan kurikulum yang } \\
\text { menentukan segala sesuatu yang } \\
\text { terjadi di dalam kelas }\end{array}$ & $\begin{array}{l}\text { Guru sebagai fasilitator yang } \\
\text { bertugas mengondisikan lingkungan } \\
\text { untuk memberikan kemudahan } \\
\text { belajar peserta didik }\end{array}$ \\
\hline 7. & $\begin{array}{l}\text { Pengetahuan, ketrampilan, dan } \\
\text { sikap dikembangkan melalui latihan, } \\
\text { seperti latihan mengerjakan soal }\end{array}$ & $\begin{array}{l}\text { Pengetahuan, ketrampilan, dan } \\
\text { sikap dikembangkan berdasarkan } \\
\text { pemahaman yang akan membentuk } \\
\text { kompetensi individual }\end{array}$ \\
\hline
\end{tabular}




\begin{tabular}{|c|l|l|}
\hline 8. & $\begin{array}{l}\text { Pembelajaran cenderung hanya } \\
\text { dilakukan di dalam kelas, atau } \\
\text { dibatasi oleh empat dinding kelas }\end{array}$ & $\begin{array}{l}\text { Pembelajaran yang dilakukan } \\
\text { mendorong terjalinnya kerja sama } \\
\text { antara sekolah, masyarakat, dan } \\
\text { dunia kerja dalam membentuk } \\
\text { kompetensi peserta didik }\end{array}$ \\
\hline 9. & $\begin{array}{l}\text { Evaluasi nasional yang tidak } \\
\text { dapat menyentuh aspek-aspek } \\
\text { kepribadian peserta didik }\end{array}$ & $\begin{array}{l}\text { Evaluasi berbasis kelas yang } \\
\text { menekankan pada proses dan hasil } \\
\text { belajar }\end{array}$ \\
\hline
\end{tabular}

\section{F. Perkembangan pengelolaan kurikulum SD di Indonesia}

Pembaharuan kurikulum SD dapat dipahami lebih baik apabila konteks historis dari pembaharuan itu diketahui. Pembaharuan atau inovasi kurikulum dimaksudkan adalah cara baru dan kreatif dalam seleksi, organisasi, dan penggunaan sumber-sumber manusia dan material yang diharapkan akan meningkatkan hasil-hasil yang berkenaan dengan tujuan yang telah dirumuskan.

Lebih lanjut, Nasution (1982: 156). menjelaskan bahwa pengembangan kurikulum pada hakikatnya sangat kompleks karena banyak faktor yang terlibat didalamnya. Tiap kurikulum didasarkan atas asas-asas tertentu,yakni

a. Asas filosofis, yang pada hakekatnya menentuksn tujuan umum pendidikannya.

b. Asas Sosiologis yang memberikan dasar untuk menentukan apa yang akan dipelajari sesuai dengan kebutuhan masyarakat, kebudayaan, perkembangan IPTEK.

c. Asas Organisatoris yang memberikan dasar-dasar,dalam bentuk bagaimana bahan pelajaran itu disusun, dan bagaimana luas dan urutannya.

d. Asas Psikologis yang memberikan prinsip-prinsip tentang perkembangan anak dalam berbagai aspek.

Pengembangan kurikulum merupakan bagian yang esensial dari progam pendidikan. Sasaran yang ingin dicapai bukanlah semata-mata memproduksi bahan pelajaran melainkan lebih untuk meningkatkan kualitas pendidikan. Perkembangan kurikulum menyangkut banyak faktor,misalnya mempertimbangkan isu-isu mengenai kurikulum,siapa yang terlibat, bagaimana proses, tujuan, kepada siapa kurikulum itu 
ditujukan. Faktor-faktor inilah yang menjadi pertimbangan untuk menyempurnakan atau mengubah kurikulum dari waktu ke waktu.

Kurikulum sekolah dasar di Indonesia telah mengalami banyak perubahan. Sejak era kemerdekaan, rangkaian perubahan kurikulum SD itu bisa diringkas sebagai berikut.

\section{Kurikulum pada awal kemerdekaan}

Ki hajar Dewantoro (1945) melakukan langkah pembaharuan sistem pendidikan dan pengajaran. Langkah awal itu adalah membuat pedoman penyelenggaraan pendidikan dan pengajaran yang berlandaskan pada falsafah kebangsaan Indonesia. Kurikulum ini menekankan bahwa pendidikan harus menguatkan rasa cinta nusa dan bangsa. (Saiful Anam, 2006: 123). Selain pembaharuan ideologi pendidikan,pada awal kemerdekaan itu juga telah disusun pembaharuan kurikulum pendidikan dan pengajaran. Kurikulum sekolah dasar lebih mengutamakan filosofisideologis. Proses penyusunannya relative singkat, tanpa disertai dengan data empiris.

\section{Kurikulum tahun 1947 (Rencana Pelajaran 1947)}

Pada masa revolusi segala sesuatu harus terselanggara secara cepat dengan sumber yang sangat terbatas. Ini berlaku juga dalam usaha membangun sistem pendidikan dan pengajaran nasionak untuk mengganti sistem kolonial, termasuk usaha menyusun Rencana Pelajaran 1947. Namun, situasi republik yang masih bergolak dan kondisi yang serba kekurangan menyebabkan Rencana Pelajaran 1947 baru bisa dilaksanakan di sekolah-sekolah pada tahun 1950. Oleh karena itu, banyak yang menyebut sejarah perkembangan kurikulum pendidikan di tanah air diawali dari kurikulum 1950. Pada perkembangannya Rencana Pelajaran 1947 lebih dirinci lagi setipa mata pelajarannya, yang dikenal dengan istilah Rencan Pelajaran Terurai 1952. (Saiful Anam, 2006: 124)

Susunan Rencana Pelajaran 1947 membedakan tiga macam struktur program, yaitu (1) untuk sekolah-sekolah yang menggunkan bahasa pengantar daerah pada kelas-kelas yang lebih rendah, (2) untuk sekolah yang menggunakan pengantar bahasa indonesia sejak kelas I, dan (3) untuk sekolah-sekolah yang diselenggarakan sore hari karena terpaksa oleh keadaan (terbatas sampai dengan kelas IV saja; kelas V dan kelasVI harus diselenggarakan pada pagi hari). 


\section{Kurikulum Tahun 1964 (Rencana Pendidikan)}

Rencana Pendidikan 1964 melahirkan kurikulum 1964, yang titik beratnya pada perkembangan daya cipta,rasa karsa,karya dan moral, yang kemudian lebih dikenal dengan istilah Pancawardhana. Disebut pancawardhana karena mata pelajaran di klasifikasikan ke dalam lima bidang studi, yaitu kelompok perkembangan moral, kecerdasan, emosional/artistik, keterempilan, dan jasmani. (Saiful Anam, 2006: 127)

Tatacara penyusunan Rencana Pendidikan 1964 dipengaruhi kondisi dimana usaha-usaha pembaharuan pendidikan dan pengajaran, terutama kurikulum dan metode mengajar sudah mulai dilembagakan secara struktural.

\section{Kurikulum Tahun 1968}

Penyusunan kurikulum 1968 merupakan usaha penertiban Rencana Pendidikan 1964. Dengan kata lain,kurikulum itu harus mencerminkan kemurnian Pancasila dan UUD 1945 sebagaimana ditetapkan dalam berbagai keputusan MPRS tahun 1966.

Kurikulum sekolah dasar 1968 masih mempertahankan 2 macam struktur program, yaitu (1) untuk sekolah-sekolah yang bahasa pengantarnya bahasa daerah sampai dengan kelas III, dan (2) untuk sekolah-sekolah yang bahasa pengantarnya dengan Bahasa Indonesia dari kelas I.

\section{Kurikulum Tahun 1975}

Pendekatan kurikulum 1975 menekankan pada tujuan, agar pendidikan lebih efisien dan efektif. Yang melatarbelakanginya adalah pengaruh konsep di bidang manajemen, Yaitu MBO (management by objective). Kurikulum sekolah dasar 1975 terdiri atas tujuh unsur pokok yang termuat dalam 3 buku, yaitu (a) Dasar, tujuan, dan prinsip-prinsip, (b) Struktur Program Kurikulum, (c) Garis besar Program Pengajaran, (d) Sistem Penyajian, (e) Sistem penilaian, (f) Sistem Bimbingan dan Penyuluhan, dan (g) Pedoman Supervisi dan Administrasi. (Saiful Anam, 2006: 129-139)

\section{Kurikulum Tahun 1984}

Pemikiran tentang perlunya perbaikan kurikulum pendidikan 
terus berkembang. Menurut para ahli kurikulum, penekanan terhadap tujuan dan materi saja tidaklah cukup untuk menghasilkan lulusan yang jempolan. Oleh karena itu,lahirlah kurikulum 1984 yang mengusung Process Skill Approach.

Kurikulum 1984 sendiri tidak mengubah semua hal pada kurikulum 1975. Meski mengutamakan pendekatan keterampilan proses, tapi faktor tujuan tetap dianggap penting. Kurikulum 1984 juga disebut sebagai kurikulum 1975 yang disempurnakan dengan konsep Cara Belajar Siswa Aktif (CBSA). Dari hal-hal yang bersifat mengamati sesuatu, mengelompokkan, mendiskusikan, hingga melaporkan, menjadi bagian penting proses belajar mengajar.

\section{Kurikulum Tahun 1994}

Polemik mengenal CBSA hanya tinggal sayup-sayup seiring dengan kehadiran kurikulum Kurikulum 1994. Kurikulum 1994 ini lebih merupakan perpaduan dari kurikulum 1975 dan 1984, atau antara pendekatan tujuan dan pendekatan proses.

\section{Kurikulum Tahun 1999 (Suplemen Kurikulum 1994)}

Kehadiran Suplemen Kurikulum 1994 ini diantaranya dilatarbelakangi terjadinya perubahan besar dalam politik di Indonesia yang dikenal sebagai Reformasi 1998. Era reformasi ini ditandai dengan berbagai perubahan penting dalam dunia pendidikan, misalnya keinginan untuk menjadikan siswa berfikir kritis, mampu melihat dan menganalisis, dan kemampuan-kemampuan lain yang tidak berkembang pada era orde baru. (Saiful Anam, 2006: 129-139) Perubahan-perubahan ini yang ingin diwadahi dalam Suplemen Kurikulum 1994 yang dibuat pada 1999.

\section{Kurikulum Tahun 2004}

Atmosfer reformasi dan iklim dunia yang cepat berubah di era globalisasi, mau tidak mau mendorong pendidikan nasional untuk terus beradaptasi. Undang-undang tentang sistem pendidikan disempurnakan dengan lahirnya Undang-undang nomor 20 tahun 2003 tentang Sistem Pendidikan Nasional. Undang-Undang ini yang melahirkan Kurikulum 2004, yang populer disebut Kurikulum Berbasis Kompetensi (KBK).

Setelah beberapa tahun Kurikulum 1994 diimplementasikan, pemerintah memandang perlu dilakukan kajian dan penyempurnaan sesuia dengan antisipasi perkembangan. Oleh karena itu sejak tahun 2001 Depdiknas melakukan serangkaian kegiatan penyempurnaan 
kurikulum 1994 dan menghasilkan Kurikulum Berbasis Kompetensi (KBK). (Mulyasa, 2006: 9)

KBK mengubah secara relative radikal kurikulum sebelumnya. Digunakannya istilah kompetensi dan life skills menandai perubahan radikal itu dalam kurikulum pendidikan indonesia. Sayangnya, KBK yang sudah diuji cobakan sejak 2001 dan telah dilaksanakan di berbagai sekolah sejak tahun 2004 tidak pernah disahkan secara resmi menjadi kurikulum nasional. Dengan demikian, KBK menjadi draf kurikulum yang akan disempurnakan lagi oleh kurikulum selanjutnya yang dikenal dengan Kurikulum Tingkat Satuan Pendidikan (KTSP).

\section{Kurikulum Tingkat Satuan Pendidikan (KTSP)}

Draf kurikulum hasil rintisan tersebut (bisa disebut kurikulum 2004) yang semula akan diberlakukan (sebut ujicoba) penerapannya di sekolah-sekolah tahun ajaran 2004-2005, namun dengan lahirnya UU Nomor 20 Tahun 2003 tentang Sistem Pendidikan Nasional dan PP Nomor 19 Tahun 2005 tentang Standar Nasional Pendidikan, draf kurikulum tersebut perlu disesuaikan kembali. (Mulyasa, 2006: 10)

Selanjutnya Badan Standard Nasional Pendidikan (BNSP) mengusulkan standar isi dan standar kompetensi lulusan yang sesuai dengan PP Nomor 19 Tahun 2005. BNSP mengembangkan panduan penyusunan Kurikulum Tingkat Satuan pendidikan (KTSP). Setiap satuan pendidikan (termasuk sekolah dasar) diharapkan dapat mengembangkan kurikulum yang diimplementasikan di satuan pendidikan masing-masing. Bagi yang belum siap mengembangkan kurikulum, dapat menggunakan model yang dikembangkan oleh BNSP dan pelaksanaannya tetap disesuiakan dengan kondisi sekolah. (Mulyasa, 2006: 11)

\section{G. Karakteristik Kurikulum Sekolah Dasar/Madrasah Ibtidaiyah a) Kerangka Dasar Kurikulum \\ 1. Kelompok Mata Pelajaran}

Sesuai dengan PP Nomor 19 Tahun 2005 tentang Standar Nasional pendidikan pasal 6 ayat (1) dinyatakan bahwa kurikulum untuk jenis pendidikan umum,kejuruan, dan khusus pada jenjang pendidikan dasar dan menengah diatur berdasarkan kelompok mata pelajaran sebagai berikut. 
a) Kelompok mata pelajaran agama dan akhlak mulia.

b) Kelompok mata pelajaran kewarganegaraan dan kepribadian.

c) Kelompok mata pelajaran ilmu pengetahuan dan teknologi.

d) Kelompok mata pelajaran estetika.

e) Kelompok mata pelajaran jasmani,olahraga, dan kesehatan.

Cakupan setiap kelompok mata pelajaran disajikan pada tabel 1 berikut.

Tabel 1: Cakupan Kelompok Mata Pelajaran

\begin{tabular}{|l|l|l|}
\hline No & $\begin{array}{c}\text { Kelompok Mata } \\
\text { Pelajaran }\end{array}$ & \multicolumn{1}{c|}{ Cakupan } \\
\hline 1. & $\begin{array}{l}\text { Agama dan Akhlak } \\
\text { Mulia }\end{array}$ & $\begin{array}{l}\text { Kelompok mata pelajaran dan akhlak mulia } \\
\text { dimaksudkan untuk membentuk peserta didik } \\
\text { menjadi manusia yang beriman dan bertakwa } \\
\text { kepada Tuhan Yang Maha Esa serta berakhlak } \\
\text { mulia. Akhlak Mulia mencakup etika, budi pekerti, } \\
\text { atau moral sebagai perwujudan dari pendidikan } \\
\text { agama. }\end{array}$ \\
\hline 2. & $\begin{array}{l}\text { Kelompok mata pelajaran kewarganegaraan dan } \\
\text { kepribadian dimaksudkan untuk peningkatan } \\
\text { kesadaran dan wawasan peserta didik akan } \\
\text { status, hak, dan kewajibannya dalam kehidupan } \\
\text { bermasyarakat, berbangsa, dan bernegara, serta } \\
\text { peningkatan kualitas dirinya sebagai manusia. } \\
\text { Kesadaran dan wawasan termasuk wawasan } \\
\text { kebangsaan, jiwa dan patriotisme bela negara, } \\
\text { dan Kepribadian } \\
\text { penghargaan terhadap hak-hak asasi manusia, } \\
\text { kemajemukan bangsa, pelestarian lingkungan } \\
\text { hidup, kesetaraan gender, demokrasi, tanggung } \\
\text { jawab sosial, ketaatan pada hukum, ketaatan } \\
\text { membayar pajak, dan sikap serta perilaku anti } \\
\text { korupsi, kolusi, dan nepotisme. }\end{array}$ \\
\hline 3. & $\begin{array}{l}\text { Kelompok mata pelajaran ilmu pengetahuan dan } \\
\text { teknologi pada SD/Ml/SDLB dimaksudkan untuk } \\
\text { mengenal, menyikapi, dan mengapresiasi ilmu } \\
\text { pengetahuan dan teknologi, serta menanamkan } \\
\text { kebiasaan berpikir dan berperilaku yang ilmiah } \\
\text { dan kritis, kreatif dan mandiri. }\end{array}$ \\
\hline IImu Pengetahuan \\
dan Teknologi
\end{tabular}




\begin{tabular}{|c|c|c|}
\hline 4. & Estetika & $\begin{array}{l}\text { Kelompok mata pelajaran estetika dimaksudkan } \\
\text { untuk meningkatkan sensitivitas, kemampuan } \\
\text { mengekspresikan dan kemampuan mengapresiasi } \\
\text { keindahan harmoni. Kemampuan mengapresiasi } \\
\text { dan mengekspresikan keindahan serta harmoni } \\
\text { mencakup apresiasi dan ekspresi, baik dalam } \\
\text { kehidupan individual sehingga mampu menikmati } \\
\text { dan mensyukuri hidup, maupun dalam kehidupan } \\
\text { kemasyarakatan sehingga mampu menciptakan } \\
\text { kebersamaan yang harmonis. }\end{array}$ \\
\hline 5. & $\begin{array}{l}\text { Jasmani, Olahraga } \\
\text { dan kesehatan }\end{array}$ & $\begin{array}{l}\text { Kelompok mata pelajaran jasmani, olahraga dan } \\
\text { kesehatan pada SD/MI/SDLB dimaksudkan untuk } \\
\text { meningkatkan potensi fisik serta menanamkan } \\
\text { sportivitas dan kesadaran hidup sehat. } \\
\text { Budaya hidup sehat termasuk kesadaran, sikap, } \\
\text { dan perilaku hidup sehat yang bersifat individual } \\
\text { ataupun yang bersifat kolektif kemasyarakatan } \\
\text { seperti keterbatasan dari perilaku seksual bebas, } \\
\text { kecanduan narkoba, HIVIAIDS, demam berdarah, } \\
\text { muntaber, dan penyakit lain yang potensial } \\
\text { mewabah. }\end{array}$ \\
\hline
\end{tabular}

Selain tujuan dan cakupan kelompok mata pelajaran sebagai bagian dari kerangka dasar kurikulum, perlu dikemukakan prinsip pengembangan kurikulum.

2. Prinsip Pengembangan Kurikulum

Kurikulum tingkat satuan pendidikan jenjang pendidikan dasar dan menengah dikembangkan oleh sekolah dan komite sekolah berpedoman pada standar kompetensi lulusan dan standar isi serta panduan penyusunan kurikulum yang dibuat oleh BSNP. Kurikulum dikembangkan berdasarkan prinsip-prinsip berikut.

a. Berpusat pada potensi,

Perkembangkan, kebutuhan, dan kepentingan peserta didik memiliki posisi sentral untuk mengembangkan kompetensinya agar menjadi manusia yang beriman dan bertakwa kepada Tuhan Yang Maha Esa, berakhlak mulia, sehat, berilmu, cakap, kreatif, mandiri dan menjadi warga negara yang demokratis serta bertanggung jawab. Untuk mendukung pencapaian tujuan tersebut pengembangan kompetensi peserta didik disesuaikan dengan 
potensi, perkembangan, kebutuhan, dan kepentingan peserta didik serta tuntunan lingkungan.

b. Beragam dan terpadu

Kurikulum dikembangkan dengan memperhatikan keragaman karakteristik peserta didik, kondisi daerah, dan jenjang serta jenis pendidikan, tanpa membedakan agama, suku, budaya, dan adat istiadat, serta status sosial ekonomi dan gender. Kurikulum meliputi substansi komponen muatan wajib kurikulum, muatan lokal, dan pengembangan diri secara terpadu, serta disusun dalam keterkaitan dan kesinambungan yang bermakna dan tepat antarsubstansi.

c. Tanggap terhadap perkembangan ilmu, pengetahuan, dan seni Kurikulum dikembangkan atas dasar kesadaran bahwa ilmu pengetahuan, teknologi dan seni berkembang secara dinamis, dan oleh karena itu semangat dan isi kurikulum mendorong peserta didik untuk mengikuti dan memanfaatkan secara tepat perkembangan ilmu pengetahuan, tekonologi, dan seni.

d. Relevan dengan kebutuhan kehidupan

Pengembangan kurikukum dilakukan dengan melibatkan pemangku kepentingan (stakeholders) untuk menjamin relevansi pendidikan dengan kebutuhan kehidupan, termasuk di dalamnya kehidupan kemasyarakatan, dunia usaha dan dunia kerja. Oleh karena itu, pengembangan keterampilan pribadi, keterampilan berpikir, keterampilan sosoial, keterampilan akademik, dan keterampilan vokasional merupakan keniscayaan.

e. Menyeluruh dan berkesinambungan

Substansi kurikulum mencakup keseluruhan dimensi kompetensi, bidang kajian keilmuan dan mata pelajaran yang direncanakan dan disajikan secara berkesinambungan antarsemua jenjang pendidikan.

f. Belajar sepanjang hayat

Kurikulum diarahkan kepada proses pengembangan, pembudayaan dan pemberdayaan peserta didik yang berlangsung sepanjang hayat. Kurikulum mencerminkan keterkaitan antara unsur-unsur pendidikan formal,non formal dan informal, dengan memperhatikan kondisi dan tuntutan lingkungan yang selalu berkembang serta 
arah pengembangan manusia seutuhnya

g. Seimbang antara kepentingan nasional dan kpentingan daerah Kurikulum dikembangkan dengan memperhatikan kepentingan nasional dan kepentingan daerah untuk membangun kehidupan bermasyarakat, berbangsa dan bernegara. Kepentingan nasional dan kepentingan daerah harus saling mengisi dam membersayakan sejalan denan motto Bhineka Tunggal Ika dalam kerangka Negara Kesatuan Republik Indonesia.

\section{Prinsip Pelaksanaan Kurikulum}

Dalam pelaksanaan kurikulum disetiap satuan pendidikan menggunakan prinsip-prinsip sebagai berikut.

a) Pelaksanaan Kurikulum didasarkan pada potensi, perkembangan dan kondisi peserta didik untuk menguasai kompetensi yang berguna bagi dirinya. Dalam hal ini peserta didik harus mendapatkan pelayanan pendidikan yang bermutu, serta memperoleh kesempatan untuk mengekspresikan dirinya secara bebas,dinamis, dan menyenangkan.

b) Kurikulum dilaksanakan dengan menegakkan kelima pilar belajar yaitu : (a) belajar untuk beriman dan bertakwa kepada Tuhan Yang Maha Esa, (b) belajar untuk memahami dan menghayati, (c) belajar untuk mampu melaksanakan dan berbuat secara efektif, (d) belajar untuk hidup bersama dan berguna bagi orang lain, dan (e) belajar untuk membangun dan menemukan jati diri, melalui proses pembelejaran yang aktif, efektif, dan menyenangkan.

c) Pelaksanaan kurikulum memungkinkan peserta didik mendapat pelayanan yang bersifat perbaikan, pengayaan,dan/atau percepatan sesuai dengan potensi, tahap perkembangan, dan kondisi peserta didik dengan tetap memperhatikan keterpaduan pengembangan pribadi peserta didik yang berdimensi ke-Tuhanan, keindividuan, kesosialan, dan moral.

d) Kurikulum dilaksanakan dalam suasana hubungan peserta didik dan pendidik yang saling menerima dan menghargai, akrab, terbuka, dan hangat, dengan prinsip tut wuri handayani, ing madia mangun karsa, ing ngarsa sing tuladha (di belakang memberikan dorongan, di tengah membangun semangat, di depan memberikan 
teladan).

e) Kurikulum dilaksanakan dengan menggunakan pendekatan multistrategi dan multimedia, sumber belajar dan teknologi yang memadai, dan memanfaatkan lingkungan sekitar sebagai sumber belajar, dengan prinsip alam takambang jadi guru (semua yang terjadi, tergelar dan berkembang di masyarakat dan lingkungan sekitar serta lingkungan alam semesta dijadikan sumber belajar, contoh dan teladan).

f) Kurikulum dilaksanakan dengan mendayagunakan kondisi alam, sosial dan budaya serta kekayaan daerah untuk keberhasilan pendidikan dengan muatan seluruh bahan kajian secara optimal.

g) Kurikulum yang mencakup seluruh komponen kompetensi mata pelajaran, muatan lokal dan pengembangan diri diselenggarakan dalam keseimbangan, keterkaitan, dan kesinambungan yang cocok dan memadai antarkelas dan jenis serta jenjang pendidikan.

\section{b) Sturktur Kurikulum}

Sturktur kurikulum merupakan pola dan susunan mata pelajaran yang harus ditempuh oleh peserta didik dalam kegiatan pembelajaran. Kedalaman muatan kurikulum pada setiap mata pelajaran pada setiap satuan pendidikan dituangkan dalam kompetensi yang harus dikuasai peserta didik sesuai dengan beban belajar yang tercantum dalam struktur kurikulum. Kompetensi yang dimaksud terdiri atas standar kompetensi dan kompetensi dasar yang dikembangkan berdasarkan standar kompetensi lulusan. Muatan lokal dan kegiatanpengembangan diri merupakan bagian integral dari struktur kurikulum pada jenjang pendidikan dasar dan menengah.

Struktur kurikulum SD/MI meliputi substansi pembelajaran yang ditempuh dalam satu jenjang pendidikan selama enam tahun mulai kelas I sampai kelas VI. Struktur kurikulum SD/MI disusun berdasarkan standar kompetensi lulusan dan standar kompetensi mata pelajaran dengan ketentuan sebagai berikut.

a) Kurikulum SD/MI memuat 8 mata pelajaran, muatan lokal, dan pengembangan diri seperti tertera pada tabel 2. Muatan lokal merupakan kegiatan kulikuler untuk mengembangkan kompetensi 
yang disesuaikan dengan ciri khas dan potensi daerah, termasuk keunggulan daerah, yang materinya tidak dapat dikelompokkan ke dalam mata pelajaran yang ada. Substansi muatan lokal ditentukan oleh satuan pendidikan.

b) Pengembangan diri bukan merupakan mata pelajaran yang harus diasuh oleh guru. Pengembangan diri bertujuan memberikan kesempatan kepada peserta didik untuk mengembangkan dan mengekspresikan diri sesuai dengan kebutuhan, bakat, dan minat setiap peserta didik sesuai dengan kondisi sekolah. Kegiatan pengembangan diri difasilitasi dan atau dibimbing oleh konselor, guru, atau tenaga kependidikan yang dapat dilakukan dalam bentuk kegiatan ekstrakulikuler. Kegiatan pengembangan diri dilakukan melalui kegiatan pelayanan konseling yang berkenaan dengan masalah diri pribadi dan kehidupan sosial, belajar, dan pengembangan karir peserta didik.

c) Substansi mata pelajaran IPA atau IPS pada SD/MI merupakan "IPA Terpadu" dan "IPS Terpadu".

d) Pembelajaran pada kelas I s.d. III dilaksanakan melalui pendekatan tematik, sedangkan pada kelas IV s.d. VI dilaksanakan melalui pendekatan mata pelajaran.

e) Jam pembelajaran untuk setiap mata pelajaran dialokasikan sebagaimana tertera dalam struktur kurikulum.

f) Alokasi waktu satu jam pembelajaran adalah 35 menit.

g) Minggu efektif dalam satu tahun pelajaran (dua semester) adalah 34-38 minggu. 
Tabel 3: Struktur Kurikulum SD/MI

\begin{tabular}{|c|c|c|c|c|}
\hline \multirow[t]{2}{*}{ Komponen } & \multicolumn{4}{|c|}{$\begin{array}{c}\text { Kelas dan Alokasi } \\
\text { Waktu }\end{array}$} \\
\hline & $\mathrm{I}$ & II & III & IV, V, VI \\
\hline A. Mata Pelajaran & & & & \\
\hline 1. Pendidikan Agama & & & & 3 \\
\hline 2. Pendidikan Kewarganegaraan & & & & 2 \\
\hline 3. Bahasa Indonesia & & & & 5 \\
\hline 4. Matematika & & & & 5 \\
\hline 5. IImu Pengetahuan Alam & & & & 4 \\
\hline 6. Ilmu Pengetahuan Sosial & & & & 3 \\
\hline 7. Seni Budaya Dan Ketrampilan & & & & 4 \\
\hline 8. Pendidikan Jasmani, Olahraga dan Kesehatan & & & & 4 \\
\hline B. Muatan Lokal & & & & 2 \\
\hline C. Pengembangan Diri & & & & $\left.2^{*}\right)$ \\
\hline Jumlah & 26 & 27 & 28 & 32 \\
\hline
\end{tabular}

\section{DAFTAR PUSTAKA}

Ashan, Mc. Competency Based Education and Training. London. Philadelphia: The Falmers Press, 1995.

Abdullah Idi, Pengembangan Kurikulum, Teori dan Praktik. Jogjakarta: Ar-Ruzz Media, 2007.

Depdiknas, Pelakasnaan Kurikulum Berbasis Kompetensi. Jakarta: Puskur Balitbang, 2002.

, Kurikulum Berbasis Kompetensi Mata Pelajaran Pendidikan Agama Islam Sekolah Menengah Umum. Jakarta: Puskur Balitbang, 2001.

E Mulyasa, Kurikulum Berbasis Kompetensi: Konsep, Karakteristik, dan Implementasi. Bandung: PT Remaja Rosdakarya, 2002.

, Kurikulum Berbasis Kompetensi. Bandung: PT Remaja Rosdakarya, 2003.

, Kurikulum Tingkat Satuan Pendidikan. Bandung: PT Remaja Rosdakarya, 2006. 
Fatah, Nanang. Manajemen Berbasis Sekolah. Bandung: CV Andira, 2000.

Kwartolo, Yuli. Catatan Kritis Tentang Kurikulum Berbasis Kompetensi. Jurnal Pendidikan Panabur, 01 Maret 2002.

Muhammad Joko Susilo, Kurikulum Tingkat Satuan Pendidikan: Manajemen Pelaksanaan dan Kesiapan Sekolah Menyongsongnya.

Mulyani Sumanta, Kurikulum dan Pengajaran. Jakarta: Departemen Pendidikan dan Kebudayaan Direktorat Jenderal Pendidikan Tinggi, 1988.

M. Ahmad, dkk. Pengembangan Kurikulum. Bandung: Pustaka Setia, 1998.

Muhaimin, Wacana Pengembangan Pendidikan Islam. Yogyakarta: Pustaka Pelajar, 2003.

Nasution, Pengembangan Kurikulum. Bandung: PT. Citra Aditya Bakti, 1990.

Nana Syaodih Sukmadinata, Pengembangan Kurikulum: Teori dan Praktek. Bandung: PT. Remaja Rosdakarya, 2005.

Oemar Hamalik, Manajemen Pengembangan Kurikulum. Bandung: Remaja Rosda Karya, 2006.

S. Nasution, Azas-azas Kurikulum. Bandung: Jemars, 1982.

Saiful Anam, Sekolah Dasar: Pergulatan Mengejar Ketertinggalan. Solo: PT. Wangsa Jatra Lestari, 2006.

Tilaar, H.A.R. Manajemen Pendidikan Nasional: Kajian Pendidikan Masa Depan. Bandung: PT Remaja Rosda Karya, 1994.

UUSPN, No. 20 Tahun 2003, Bab 1 Ayat 19. 